\title{
Managed care \& conflict of interest
}

In Arizona, a group of patients in a managed care program called Intergroup Healthcare Corporation sued the company for insurance fraud, breach of fiduciary responsibility and failure to provide informed consent. Why? Because Intergroup failed to disclose to patients covered by its insurance that their physicians were being paid under a plan that offered cash incentives and bonuses to those doctors who kept medical tests to a minimum and refrained from referring patients to specialists under all but the most dire circumstances. no one denies that the United States spends too much money on health care, especially in contrast to Canada and European nations. For reasons that in retrospect look silly (and weren't convincing even at the time), Congress decided in the early 1970 s that a doctor shortage was imminent, leading to the foundation of new medical schools and increased class size in existing institutions. As the number of doctors increased, so did the number of medical tests, surgical procedures, and drugs that save lives or keep the chronically ill in better shape that would otherwise be the case. All this costs money, thus, the rush to a market or capitalist-driven attempt to control expenditures by limiting unnecessary care and negotiating physician services at reduced fees.

The problem arises when people believe,

Two months ago, Aetna, another company, became the subject of a lawsuit regarding quality of care under managed care or "capitated" contracts in which the health-care provider receives a fixed amount of income per patient enrolled in the plan, regardless of the real costs of caring for the patient. In this case, a physician-patient advocacy group called Code Blue, Inc., of Irvington, New York, has sued the New York State Commissioner of Health for allegedly failing to execute her duty to review managed care contracts "containing financial incentives to limit patient care . ..."

Although these lawsuits, the early wave of what promises to be a flood of suits against health plans that limit care in the name of reducing medical costs, contain the unproved presumption that limits to care are necessarily bad, the relief that patients and physicians seek emphasizes issues such as full disclosure and the right to contest bureaucratic decisions.

Adding to the mix is a recent campaign by the notfor-profit National Health Council to convince managed care companies to endorse its "Patients First" campaign. The council, based in Washington, DC, represents dozens of "voluntary" health groups that are common in the United States - groups such as the American Cancer Society, the American Lung Association and the Arthritis Foundation. One of the ten rights it espouses is the patients' right to know what their doctors are being paid and what kind of incentives and bonuses they are offered for managing care in a way that, in effect, limits Americans treasured belief in the right to get whatever care they want, whenever they want it.

This is, in some ways, a very complex issue. Virtually rightly or wrongly, that physicians' loyalty now belongs to the companies that pay them rather than the patients for whom they are supposed to care. It is worth noting that a little-discussed potential conflict of interest has long existed (and sometimes been exploited) under the fee-for-service system, which gave doctors a financial edge if they ordered the maximum number of tests or opted first for high-technology diagnostic or therapeutic measures. But in that situation, the patient generally had little to lose. Insurance paid the bill and, for the most part, patients were not injured by excess care.

The issue is quite different now, both psychologically and medically. There is good evidence that a relationship of mutual respect and trust between doctor and patient is a healing one. To the extent that the switch to managed care in the name of sound economy is undermining that trust, the system is undermining patients' legitimate need to be able to trust that their physicians are first and foremost on their side.

The answer is not necessarily to eliminate physician incentives to keep costs down by limiting care, especially not if the care meets patients' medical needs. There are anecdotal reports of patients who have been harmed because they were denied certain care, but there is also anecdotal evidence that physicians in the better managed care plans are providing excellent medicine. On that score, the data simply are not in.

But in the meantime, one thing is certain - full disclosure should now become a basic element of all health insurance programs. Patients should know how their doctors are being paid.

- Barbara J. Culliton 